\title{
ASSESSING CIVIL SERVANTS TRAINING NEEDS: THE CASE OF KAZAKHSTAN
}

\author{
Gulimzhan K. Suleimenova \\ Dr., Ph.D. in Economics, National Consultant of the UNDP in Kazakhstan. \\ Address: 10652 Str., Astana, 010000, Republic of Kazakhstan. \\ E-mail: GK.Suleimenova@gmail.com
}

\section{Zukhra T. Karamalayeva}

MSc. in Educational Leadership, Head of the Office for Civil Servants Career Planning and Professional Growth Programs Development and Analysis, Institute for Civil Servants Executive Education, Academy of Public Administration under the President of the Republic of Kazakhstan. Address: 33A Abay Str., Astana, 010000, Republic of Kazakhstan.

E-mail: zukhra.karamalayeva@gmail.com

\begin{abstract}
Under the current conditions in forming the corps of civil servants, the professionalism and competence of civil servants comes to be of paramount importance. The pace of deterioration in the growth of knowledge has lead to objectively emerging contradictions between civil servants' competency and continuously emerging new technologies. Therefore, continuous training is the basis for the constant improvement of knowledge and acquiring new socially important skills for civil servants in Kazakhstan. However, it often happens that in practice the planning of an educational process is carried out without a preliminary assessment of training needs, which leads to inefficiency in the whole learning process. The purpose of this article is to identify the main areas needed for the training of civil servants in Kazakhstan. This article is a report on a conducted study which focuses on the following research questions: (1) What are the common problems regarding knowledge and skills among civil servants? (2) What training content is currently required for civil servants? Research methods include online questionnaires and focus groups with civil servants, as well as interviews with international experts. Key areas of professional development in the civil service have been identified based on the respondents' answers. The results confirm that civil servants universally recognize that certainly there are some gaps between what is required to perform their work completely and what they actually know. The focus and methodology of the training also requires critical attention.
\end{abstract}

Keywords: civil service; competencies; training needs assessment; Kazakhstan.

Citation: Suleimenova, G.K. \& Karamalayeva, Z.T. (2018). Assessing Civil Servants Training Needs: the Case of Kazakhstan. Public Administration Issues, Special Issue (electronic edition), pp. 96-115 (in English); DOI: 10.17323/1999-5431-2018-0-5-96-115. 


\section{Introduction}

Nowadays, the set of private and corporate interests is characterized by constant dynamics and the situational variability of its quantitative, qualitative and content parameters depending on the decisions made by the government and the actions it carries out, as well as the changes in the current social, economic and political situation in the country. Interests of stakeholder groups that are not taken into account and aggregated by the government, creates the threat of a loss of socio-political stability and sustainability in public administration and in the political system as a whole (Nisnevich, 2012). Political leaders are also required to demonstrate a high level of expertise as today they have to work under conditions of constant instability and the unpredictability of a rapidly changing world (Kramer, 2016; Kazhyken, 2015).

The role of the civil service is vital in the planning, implementation and evaluation of policies and programs formulated by the political leadership. A critical issue in this context is the development of a competent and motivated civil service to assist in realizing national aspirations for rapid social and economic development which is currently complemented with the world crisis in the financial and economic sectors (Barabashev, 2016; Asatryan, Heinemann, Pitlik, 2015). It has been observed that there is a certain time lag between new innovative breakthroughs and their adjustment by public administration systems (Matei, Bujac, 2016). As a result, there is a search for new opportunities, directions and tools for further development (Lopez, 2017; Rivolin, 2017). Moreover, a crucial quality of the civil service involves its capacity to adapt and respond to the consequences of domestic and international challenges. Late-century issues including global economic crisis, increasing expansion of globalization and migration processes coupled with the rise and influence of civil society organizations, terrorism and corruption are some of the examples of those challenges that civil servants currently have to deal with (Franko, Stamos Jr., 2017; Mosley, Singer, 2015).

All these challenges have intensified the call for effective civil service education and training for building civil servants' capacity to meet constantly changing requirements. There is an urgent need to modify training systems and provide civil servants with a complex of knowledge and skills, so-called "competencies" necessary to successfully perform their duties. The recognition of the importance of civil servants' competencies development is the basis for the implementation of various training programs. This is because there is always a certain discrepancy between the content of training and the actual training needs of civil servants. In other words, there are some "learning gaps" between the knowledge required for the effective performance of official duties, and the knowledge of the civil servant himself.

Since its independence, public administration in Kazakhstan had also faced numerous challenges as a consequence of the transition period when the Communist model of public administration was shifted towards the Kazakhstani model of a market-based economy. (National Digital History, 2017). This resulted in a number of reform initiatives including civil service reform, decentralization, e-governance, etc. (Barabashev, Klimenko, 2017; Janenova, Kim, 2016; 
Nemec, 2014; Bhuyian, Amagoh, 2011). All these reforms are essential in driving a civil service towards the successful implementation of government projects, programs and policies. Consequently, civil servants were in desperate need of upgrading their skills and knowledge in order to adequately respond to these changes. As a result, civil service training has long been recognized as an important activity within the civil service of independent Kazakhstan.

\section{Civil servant training in Kazakhstan}

Over the years following independence, Kazakhstan has formed a system of training civil servants with its own inherent structure and model of training which meets the overall needs of the civil servants (Suleimenova, 2016; Suleimenova, Demeuova, 2014). The existing training model for local civil servants, in particular, was implemented in 2004 and followed the 2000 Concept of Civil Servant Training. The current model is a framework model and represents two main areas of civil servant training: retraining and upgrading qualifications training. In general, over the years, the current model allowed numerous issues to be resolved, i.e. ensuring training coverage for civil servants of all categories.

The system of civil servant training that functions in different countries, to a certain extent correlates with the civil service model and is mainly based on a competency-based approach (Podger, 2016; Knassmuller, Veit, 2015; Civil Service: Training and Development, 2014; Barabashev, 2011). In countries with a positional model of civil service, civil servant training is comprised of two components: training organized at the request of a trainee's personal and professional goals, and training for specific programs focused on obtaining relevant experience in practice. There is another model of executive education - "renewable" education (Podger, 2016). For instance, in European countries where continuous education is widely spread, trainings on executive programs are conducted in specialized university centers of continuing education (Reichard, 2016).

In the light of recent reforms in the civil service of Kazakhstan, there have been significant changes in the "Public Positions Register" as well as in procedures for entering the civil service. For instance, civil servants' performance assessment was introduced as well as certain arrangements being carried out for the transition to a new wage system. Altogether, these changes lead to the design of a career model for the civil service. (Information on the main results of activity in the sphere of civil service for 2015 and 2016, n.d; The realization of the new model of civil service, 2017). The current model of civil servant training, the foundations of which were laid in 2004, requires revision. One of the steps in this direction was the legislative recognition in 2015 which provides that all civil servants should upgrade their qualifications no less than once every three years (Article 34 of the Law on Civil Servants of the Republic of Kazakhstan, 2015). Thus, the Kazakh model of training civil servants can be referred to the type of "renewable education". In other words, it can be defined as "continuous professional training".

Despite the fact that under the law, HR management departments of government agencies are responsible for organizing the training of civil servants (Law of 
the Republic of Kazakhstan, 2015), the planning of the training process in the government agencies is often carried out without a preliminary assessment of training needs. As a result, the planned seminars (a) do not always meet the participants' expectations; (b) the knowledge acquired during the training is not in demand in practical work. Therefore, in the majority of cases the training process does not fill the "gap" in the knowledge (Kim, 2016; Poor, 2008).

The main problem in Kazakhstan is that the HR management departments of government agencies are initially guided by the norms of legislation based on the requirement of timely completion of trainings by civil servants. Primarily, the role of the HR management departments of government agencies is to timely direct the training of a civil servant.

We believe that training needs assessment is crucial in determining the "learning gaps" between the current and desired outcomes needed to perform the job successfully in the future. To quote Balisi (2014), "If needs assessment is not carried out, training programmes may have the wrong content, objectives and methods, and this means money is spent on training programmes that are unnecessary" (p. 138). Therefore, we have made an attempt to identify Kazakhstani administrative civil servants' corps 'B' basic training needs ${ }^{1}$. This article seeks to achieve a better understanding of civil servant training needs by soliciting their opinions as well as the perceptions of international experts on this matter. On the basis of the purpose of the study, the following central question was developed: What are the civil servants' basic training needs in Kazakhstan?

Civil servants and international experts' perspectives were examined from several aspects in order to address the central questions of the study:

SQ (1) What are the gaps in knowledge and skills among civil servants?

SQ (2) What training content is currently needed for civil servants?

SQ (3) What learning modalities are effective to use?

Though there is a great deal of contemporary interest in public administration reform in Kazakhstan, there is little research done on civil service training in Kazakhstan. Moreover, there is an absence of studies exclusively on civil servants' training needs assessment in Kazakhstan which, as we have mentioned, is the cornerstone in training program planning. It is hoped that this study will make a unique contribution to the development of civil servants' executive education in Kazakhstan.

With the further development of Kazakhstan as well as the crucial quality of the civil service involving its capacity to adapt and respond to the consequences of domestic and international challenges, it is necessary to train civil servants to be highly competent to adjust to all these current changes. Thus, the study is intended to play a significant role in the country's further socio-economic development.

\footnotetext{
1 The article is not aimed at studying the training needs of political civil servants and administrative civil servants of corps "A". They refer to the high level of civil service, and their functional responsibilities are concentrated on policymaking and decision-making level. It is obvious that their training needs will be significantly different from the executive level. According to statistical data, the share of above mentioned in groups of public positions accounts for $1 \%$, while the share of administrative public positions of corps " $\mathrm{B}$ " is $99 \%$.
} 


\section{Training needs assessment: international experience}

Development of civil servants' potential is a priority in human resource management (VanWart, Hondeghem, Schwella, Suino, 2015). While previously, the emphasis was on knowledge-based education, currently the training is more focused on the development of competencies needed for the successful implementation of various projects (Poor, 2006). This is supported by the fact that many countries have developed such competency models for training of civil servants such as Senior Executive Leadership Capability Framework (Australia), Federal Competency Model (Belgium), Senior Civil Servants Competency Framework (UK), Key Leadership Competencies Profile (Canada), Executive Core Qualifications (USA), Competency Framework of DPSA (South Africa), Government Standard Competency (South Korea). However, it is important to note that today competency models are not constant and often revised over time. The dynamism of the information age forms ever new challenges which in turn require new competencies. As Stephen (2001) pointed out “...competent employees don't remain competent forever. Skills deteriorate and can become obsolete. That's why organizations spend billions of dollars each year on formal training..." (p. 480). A striking example of this is the model of competencies for British civil servants (Civil Service Competency Framework, 2015).

Often, the difference between the regulated value of the specific competences and the actual behaviour of the employee is a basis for education and training planning. The process of identifying this difference is called the assessment of training needs. It is an integral element of the planning process for the development of civil servants. (The OPM: Training Needs Analysis, n.d.; Mulang, 2015; Chang, Chiang, Kun yi, 2012; Dukhnich, 2007; Fourie, 2004).

The interest in assessing the training needs is expressed by the government agencies and training centers that implement educational programs.

Meanwhile, the needs identified during assessment within the government agency, are classified into different levels. There could be three levels (OPM: Training Needs Analysis; Manning, Agere, 2002), and in some cases, four levels of needs (Haslinda, 2009; Poor, 2006; Applegarth, 1991). In our case:

1. Corporate level (on a scale of the government agency);

2. Divisional level (on a scale of the structural division);

3. Workplace level (on a scale of one workplace);

4. Individual level.

Each government agency has its own mission and strategic goals. It is very important that all structural divisions have a common vision and shared corporate values. Therefore, initially the staff development system should be built based on the mission, the perspective vision on development, and the strategic objectives of the government agency. Of course, each structural division implementing the various functions has its own specific training needs and each workplace includes its own requirements of employees that form the needs of a more local nature. At the same time, each employee is motivated by his own interests and individual training needs. Proper needs identification and subsequent identification of training objectives, as well as resources needed to implement the training strategy, will help to organize an effective educational process. At this point, the motivational aspect plays 
a significant role as the readiness and willingness of the civil servant to work is one of the key factors of the successful operation of the government agency as well as effective organizational performance (Randma-Liiv, Merilin \& Külli, 2013). In this case, it can be noted that without internal motivation an employee would not develop his competencies. As a result it can effect on his performance. In other words "...motivation indirectly through competency affect performance..." (Subari, Riady, p. 144, 2015).

For training centers it is also extremely important to conduct a preliminary assessment of training needs prior to the development of any educational programs. This will provide information about the target group, such as: number of trainees, their types of work, their interests, age and gender, gender composition, and others. Such information is useful for the selection of examples, case studies for discussion in the group, terminology, methods and forms of training. Research has shown that the attitude of civil servants to training depends on their demographic characteristics. There is also a high correlation between the assessment of needs in training, planning, and the implementation of a training program and assessment of its effectiveness (Rodic, Vucovic, Zarsnik, Miglik, 2012). Therefore, it is possible to prepare the practice-oriented training materials that will ensure effective learning.

In general, the process of training needs assessment consists of five steps:

1. Identifying problems and needs;

2. Determining assessment method;

3. Collecting the data;

4. Analyzing the data;

5. Providing feedback (Manual on Training Needs Assessment).

Studies carried out in Eastern Europe have shown that there are three different approaches for the identification of training needs in civil service (Demmke, Hammerschmid, Meyer, 2006) which are presented in a more generalized perspective:

- centralized approach, according to which the needs assessment process in training is centralized;

- decentralized approach, according to which each government agency independently exercise the training needs assessment process;

- semi-decentralized approach, according to which the strategy and structure are defined and managed centrally, but the training needs assessment process is carried out by each government agency independently.

Serbia, for instance, has identified the structure and procedures of the training needs assessment for civil servants. Each government agency is obliged to assess the training needs of their employees. In addition, the central institution for training civil servants should also identify the needs of civil servants in training (Miglic, 2006).

The Law on Civil Service of Slovenia stipulates that the heads of government agencies are responsible for the professional development of civil servants. Thus, the line management plays an essential role in identifying the need for training, while the human resources Departments bear primary responsibility for the development and implementation of training activities. As a consequence, most of the decisions on the needs and priorities of training are based on the views of the heads of departments (Rodic, et al., 2012). In practice, the vision of the training needs for the manager and the staff are always different. In particular, in South 
Africa the mid-level managers were asked to assess the "gap" between the knowledge required for the effective performance of official duties, and their own knowledge. In this case the need for training the mid-level managers had been assessed by their own supervisors. Results of the study revealed disagreements between the self-assessment of mid-level management and the assessment of their knowledge by supervisors. So, if the mid-level manager in the course of self-assessment noted that his need to develop such a competency as "Problem Solving and Decision Making" amounted to 32.5\%, then supervisors evaluated it as 50\% (Fourie, 2004). In this case, the assessment of supervisors not only ensures the credibility of a training needs assessment, but also confirms the need for training.

In general, the training centers must pay inordinate attention to the identification of training needs among potential participants before approving professional development workshops calendar. By focusing on exploring civil servants as well as international experts' opinions on current training needs, this study makes an attempt to identify the main areas needed for civil servant training in Kazakhstan.

\section{Research methodology}

The process of the training needs assessment was aimed at identifying the general gaps in the knowledge and skills that exist among civil servants.

Mixed methodology is adopted in this study to explore civil servants current training needs. Data are drawn from a survey and focus groups with in-service civil servants, and semi-structured, open-ended interviews with international experts working in Kazakhstan or having experience working with Kazakhstani partners. The interviews and focus groups aided interpretation of our statistical model, thereby enhancing the importance of this research. In fact, each instrument has its advantages and disadvantages (Barbazette, 2006). Thus, it is recommended to use them in combination.

Analysis of various sources (Chang, et al., 2012; Topno, 2012; The OPM Training Evaluation Field Guide, n.d.) has allowed us to develop our own approach to the training needs assessment. We decided that a survey using questionnaires would be conducted in 2014 and 2015, focus groups and interviews with experts in 2016.

Figure

\section{The methodological approach to the evaluation of training needs}

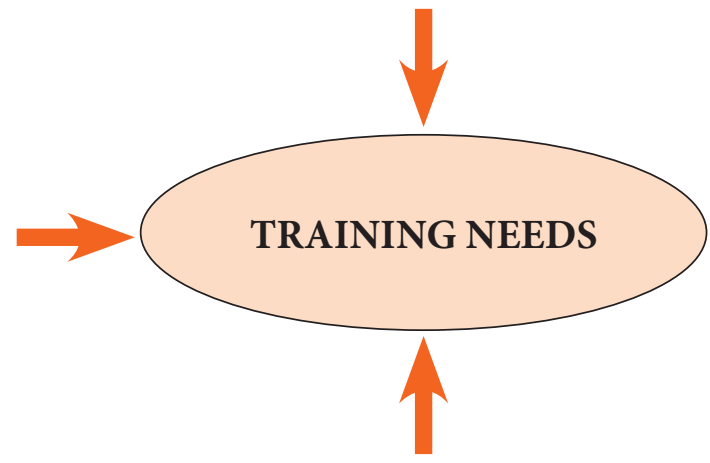


The "Bottom" approach suggests the use of a quantitative method, i.e. conducting a survey with civil servants, in the course of which individual opinions on the training needs were identified. In order to implement this approach, we developed a questionnaire. The questionnaire contained questions aimed at identifying the domains in which civil servants are challenged with needs in knowledge and skills. Civil servants were asked to answer open questions indicating an approximate list of knowledge and skills for choice as well as the opportunity to add personal opinion. Respondents were asked to answer three sets of questions such as: (1) What are the most complicated issues/tasks you have to fulfill at work? (2) What are the reasons that make it difficult to perform these tasks; (3) What skills and knowledge are needed in order to overcome these difficulties?

The survey was conducted online in the summers of 2014 and 2015, and identified the training needs during this period of time. The questionnaire was posted on the website of the Academy of Public Administration under the President of the Republic of Kazakhstan. The information, with an invitation to participate in an anonymous survey, was sent to civil servants' email addresses. The sampling amounted to 138 respondents in 2014 and 258 respondents in 2015. The information collected in the survey was largely the result of self-assessment.

It should be noted that it is common practice to conduct surveys via the HR management departments. With this approach, the questionnaire is mainly filled out by the employees of HR management departments and line managers. For that reason, the needs were mostly identified through the prism of views of the managers and employees of HR management departments. Thus, the survey was conducted by a team from the Institute for Civil Servants Executive Education in close cooperation with the government agencies' human resources management services.

For the "Top" approach, we used a qualitative method - focus groups with civil servants in managerial positions aimed at the study of their own views on training needs, better understanding of information collected during the survey, and the generation of ideas regarding ways to improve training programs. In order to conduct the focus groups, target groups were formed, and the list of questions was made in a specific sequence and with a certain structure. The civil servants were asked open questions on how they understand the notion of "upgrading qualifications", what kind of knowledge and skills they lack while performing their functional duties, as well as what they would suggest as ways to overcome all the related issues, etc. A total of 78 civil servants ( 59 of which hold managerial positions) participated in 13 focus groups.

Within the qualitative paradigm we also used semi-structured, open-ended interviews with five international experts working in Kazakhstan or having experience working with Kazakhstani partners. This was the part of "Outside point of view" assessment.

Thus, the connection between the structural validity of the questionnaire and the current model of civil servants' executive education was provided through interconnected questions that help to identify training needs as the basics of continuous professional development. 
Results of the study

\section{Characteristics of respondents}

According to the Ministry of Civil Service Affairs of the Republic of Kazakhstan, $9 \%$ of the total staff number of civil servants work in the central government agencies, $43 \%$ in the territorial divisions of the central government agencies in the regions, and $48 \%$ in the local executive bodies (Agency of the Republic of Kazakhstan for civil service and anticorruption, 2016).

In 2014, 138 civil servants participated in the online survey and 258 civil servants in 2015. However, a considerable number of the civil servants who answered the questions in the online questionnaires were representatives of local executive agencies.

Table 1

Number of Respondents

\begin{tabular}{|l|c|c|c|c|}
\hline \multirow{2}{*}{} & \multicolumn{2}{|c|}{ Central government agencies } & \multicolumn{2}{c|}{ Local executive bodies } \\
\cline { 2 - 5 } & $\mathbf{2 0 1 4}$ & $\mathbf{2 0 1 5}$ & $\mathbf{2 0 1 4}$ & 2015 \\
\cline { 2 - 5 } & Number (\%) & Number (\%) & Number (\%) & Number (\%) \\
\hline $\begin{array}{l}\text { Total number } \\
\text { of respondents }\end{array}$ & $46(33.3)$ & $90(35)$ & $92(66.7)$ & $168(65)$ \\
\hline
\end{tabular}

Characteristics of the respondents in the context of work experience in public service shows that the greater interest in online questionnaires was by government officials with over 10 years of experience.

Table 2

Experience of the Respondents in Public Service

\begin{tabular}{|l|c|c|}
\hline \multicolumn{1}{|c}{$\begin{array}{c}\text { Work experience } \\
\text { in public service }\end{array}$} & Number (\%) & 2015 \\
\cline { 2 - 3 } & $14(10.1)$ & $38(14.6)$ \\
\hline less than 1 year & $20(14.5)$ & $40(15.7)$ \\
\hline from 1 year to 3 years & $13(9.4)$ & $27(10.6)$ \\
\hline from 3 year to 5 years & $28(20.3)$ & $50(19.3)$ \\
\hline from 5 year to 10 years & $63(45.7)$ & $103(39.8)$ \\
\hline from 10 years and over & & \\
\hline
\end{tabular}

\section{Quantitative findings}

In terms of the most important issues/tasks, respondents chose answers by the level of importance and could offer their own suggestions. The distribution of answers for 2014-2015 shows that the respondents' perception changed over time. 


\section{Distribution of Responders' Answers to the Question "What are the most complicated issues/issues/tasks you have to solve at work?" by the level of importance, \%}

\begin{tabular}{|l|c|c|c|}
\hline & $\mathbf{2 0 1 4}$ & $\mathbf{2 0 1 5}$ & $\begin{array}{c}\text { Difference between } \\
\mathbf{2 0 1 4} \text { and 2015 }\end{array}$ \\
\hline $\begin{array}{l}\text { Conducting negotiations and protecting position of } \\
\text { the department }\end{array}$ & 31.2 & 14.3 & $16.9 \downarrow$ \\
\hline Delegation of authority, distribution of tasks & 18.8 & 9 & $9.8 \downarrow$ \\
\hline Preparation of analytical reports, letters, etc. & 53.6 & 21.3 & $32.3 \downarrow$ \\
\hline Preparation of letters in the State language & 21 & 21 & - \\
\hline $\begin{array}{l}\text { Development and adoption of decisions on the basis } \\
\text { of the plan analysis }\end{array}$ & 44.2 & 17.9 & $26.3 \downarrow$ \\
\hline $\begin{array}{l}\text { Development and defense of the plans, projects and/ } \\
\text { or programs }\end{array}$ & 40.5 & 21.3 & $19.2 \downarrow$ \\
\hline Organization and conducting of meetings & 13 & 7.5 & $5.5 \downarrow$ \\
\hline
\end{tabular}

In order to identify the reasons that make it difficult to perform complicated tasks, respondents were offered multiple choice questions. During the ranking of the results, we found that the opinions of the respondents in 2014 and 2015 coincided. Civil servants pointed out that the main reasons were "the lack of skills in research and application of analytical methods", then "the lack of competencies to formulate, implement and evaluate policies", "lack of decision-making competencies", etc.

Table 4

Ranking of the largest gaps in competencies, according to the respondents, by the level of importance

\begin{tabular}{|c|l|l|}
\hline Ranking & \multicolumn{1}{|c|}{2014} & \multicolumn{1}{|c|}{2015} \\
\hline 1 & $\begin{array}{l}\text { Lack of skills in research and application } \\
\text { of analytical methods }\end{array}$ & $\begin{array}{l}\text { Lack of skills in research and application } \\
\text { of analytical methods }\end{array}$ \\
\hline 2 & $\begin{array}{l}\text { Lack of competencies to formulate, } \\
\text { implement and evaluate policies }\end{array}$ & $\begin{array}{l}\text { Lack of competencies to formulate, } \\
\text { implement and evaluate policies }\end{array}$ \\
\hline 3 & $\begin{array}{l}\text { Lack of competencies required for } \\
\text { development and decision-making }\end{array}$ & $\begin{array}{l}\text { Lack of competencies required for } \\
\text { development and decision-making }\end{array}$ \\
\hline 5 & $\begin{array}{l}\text { Lack of competencies required to perform } \\
\text { leadership functions }\end{array}$ & $\begin{array}{l}\text { Lack of competencies required to perform } \\
\text { leadership functions }\end{array}$ \\
\hline 5 & $\begin{array}{l}\text { Lack of competencies required for } \\
\text { co-operation, communication and interaction }\end{array}$ & $\begin{array}{l}\text { Lack of competencies required for co- } \\
\text { operation, communication and interaction }\end{array}$ \\
\hline 6 & $\begin{array}{l}\text { Lack of presentation and speech-writing } \\
\text { skills }\end{array}$ & $\begin{array}{l}\text { Lack of presentation and speech-writing } \\
\text { skills }\end{array}$ \\
\hline 7 & Lack of negotiation skills & Lack of negotiation skills \\
\hline
\end{tabular}


It should be noted that in the category "other complicated tasks" the respondents were required to fulfill, a significant number of the respondents included various tasks, which together reflect the "communication barriers" within the domestic government agency. This means that many people lack communication skills.

At the same time, "the lack of competencies required for co-operation, communication and interaction" occupies 5th place in the ranking, and "the lack of negotiation skills" is in 7th position. Based on this, we conclude that in no way do the civil servants attribute "communication barriers" within the domestic government agency to their own lack of communication skills.

The most frequent answers to additional question on what other competencies the civil servants were lacking were "lack of time" and "lack of competent staff".

The comparative analysis of respondents' answers for 2014 and 2015 regarding required knowledge and skills necessary to overcome emerging challenges demonstrated a "contextuality" of needs.

\section{Ranking of the Knowledge and Skills required to fill the gaps in competencies}

\begin{tabular}{|c|c|c|}
\hline Ranking & 2014 & 2015 \\
\hline 1 & Ability to conduct research, analysis, etc. & Ability to conduct research, analysis, etc. \\
\hline 2 & Strategic planning and budgeting skills & Project and program management skills \\
\hline 3 & $\begin{array}{l}\text { Fundamental knowledge of policy } \\
\text { definition, implementation } \\
\text { and evaluation }\end{array}$ & Ability to develop and make decisions \\
\hline 4 & Ability to develop and make decisions & $\begin{array}{l}\text { Fundamental knowledge of policy } \\
\text { definition, implementation and evaluation }\end{array}$ \\
\hline 5 & Project and program management skills & $\begin{array}{l}\text { Knowledge of the psychology of } \\
\text { management }\end{array}$ \\
\hline 6 & $\begin{array}{l}\text { Knowledge of the psychology of } \\
\text { management }\end{array}$ & Strategic planning and budgeting skills \\
\hline 7 & Basic knowledge of the rulemaking & $\begin{array}{l}\text { Ability to collaborate, communicate, and } \\
\text { interact }\end{array}$ \\
\hline 8 & $\begin{array}{l}\text { Knowledge of the change management } \\
\text { peculiarities }\end{array}$ & $\begin{array}{l}\text { Knowledge of the change management } \\
\text { peculiarities }\end{array}$ \\
\hline 9 & $\begin{array}{l}\text { Ability to collaborate, communicate, and } \\
\text { interact }\end{array}$ & Basic knowledge of the rulemaking \\
\hline
\end{tabular}

If, in 2014, the first three places in the ranking were: "ability to conduct research, analysis, etc.", "strategic planning and budgeting skills", and "fundamental knowledge of policy definition, implementation and evaluation", then in 2015 the first three places were occupied by: "ability to conduct research, analysis, etc.", 
"project and program management skills", and "ability to make right decisions". This rating indicates that the training needs change over time.

\section{Qualitative findings}

\section{Focus Group Results}

During the period of April-May 2016, 13 focus groups were held, which were attended by a total of 78 civil servants. The following questions were prepared for focus group discussions: (1) What qualities are civil servants required to have for the effective performance of their functional duties?" (2) What do you understand by professional development? (3) What training content is required for civil servants? (4) What learning modalities are effective to use?

Four themes describing which qualities civil servants need to have were identified:

1. Being professional;

2. Being competent/having specific competencies to fulfill the tasks;

3. Ability to make their own decisions;

4. Following the ethical guidelines.

In terms of the second question on the meaning of professional development, participants expressed the following. In the participants' opinions, professional development is the "exchange of experiences; new perspective and new information", "additional knowledge that will be useful in the course of my work", "a person must come and learn something new for himself, and after, apply it in his work place", and so on. The answers received indicated that civil servants put a slightly different meaning to the term "professional development", which generally coincides with the concept laid down in Article 34 of the Law on Civil Services of the Republic of Kazakhstan. In the Law, the term "professional development" includes training seminars aimed at competency improvement.

While the answers of the focus group participants to the two previous questions varied and generally represented the "reasoning" nature, the answers to the third question: "What training content is required for civil servants?" were precise and similar. The answers can be divided into three themes:

Communication skills, following ethical guidelines. Here are some of the views:

"If the main objective of the civil servant is a provision of public services and work with the general public, than certainly, it shall be a communication skills direction. It is necessary that he complies with the ethics and is able to resolve a conflict situation ..."

"This is the ethical standard for civil servants and their ability to communicate with the population."

"It is necessary to conduct lectures on development of moral and determination qualities, develop communication skills in particular ...."

Development of leadership skills. Participants of focus groups showed great concern towards the need to improve the competencies of managers and to develop their leadership skills. Participants offered to organise the seminars on 
the following topics: Management for Executives; Time Management for Executives. Here are some of the comments:

"I will pass the management course again.... I would like our managers to attend these management courses on a mandatory basis ...";

"... Managers have to undergo some kind of professional development of a psychological nature ...";

"There is no proper management, no proper planning .... Our managers

say ... here you are, I assign this task to you, you do it ...".

Third group. Participants touched on the highly specialized topics arising from specific activities of the government agency, such as strategic management; the specifics of public policy development, realization and evaluation; globalization and national security; project management strategies, instruments and tactics; performance management; public policy effectiveness evaluation, etc.

To the question "What learning modalities are effective to use?" participants suggested:

1. Form target groups whereby civil servants are exercising the same duties in one group;

2. Develop differentiated programs for managers and executives;

3. Conduct offsite training;

4. Implement corporate training;

5. Apply active forms of training, such as working in small groups, etc.

In general, the results of the focus groups, in addition to the questionnaire, allowed us to define the attitude of civil servants towards training and identify their understanding of training.

At the same time, in the survey results, respondents noted the presence of "communication barriers", but did not evaluate the priority status of civil servants communication skills development as high. The results of the focus groups have shown the paramount importance of the development of the communication skills of civil servants together with the development of ethics.

\section{Interviews with the Experts}

During the study, semi-structured, open-ended interviews were conducted with five international experts, who are in one way or the other familiar with the government structure of Kazakhstan.

In order to identify the experts' opinions on current civil servant training needs, four basic questions were prepared: (1) What challenges may the public sector of Kazakhstan face within the next five years; (2) What competencies should civil servants in Kazakhstan develop in order to meet these challenges? (3) What kind of training courses do you believe it will be necessary to design to help civil servants develop the above mentioned competencies? (4) What other professional development learning modalities do you recommend implementing?

Regarding the challenges to be faced by the public sector of Kazakhstan within the next five years, the majority of experts have noted that the falling price of oil, the unstable economic situation worldwide, the need to diversify the economy, and the problem of centralized public administration (the "top- 
down" principle) are the most likely challenges for Kazakhstan in the long term perspective. These are some of the expert comments:

"The first one, of course, will be the oil price because with falling of oil prices you're gonna have budget problems. Budget problems mean that you have to think about allocating your resources in an efficient manner ...";

"... The main challenges of course refer to the raw materials orientation of the economy. And there is absolutely no doubt about the need to diversify the economy of the country ...";

"There is a real need if you want to diversify the economy, there is a real need to have rather detailed planning at this level and rather detailed development of initiatives and so on. And actually the issue is that all of this in the region requires different public actors to be able to work together, ok? The key issue is the following. In your system, there is a still very, very vertical ...".

One of the respondents in his comments noted, that the public sector in the next five years might encounter such problems as setting higher requirements regarding the quality of services from the business and public sectors; the outflow of highly qualified personnel to the private sector; and a reduction in the state apparatus and the need to improve the efficiency of current business processes.

Concerning the competencies required for civil servants to solve the above challenges, a number of experts indicated the importance of leadership development, strategic thinking, communication skills of civil servants, ability to manage changes, and effective management skills. Here's how the experts commented on the importance of some of these areas:

"First of all, you need to improve leadership skills. That is a very horizontal thing. You do need, especially I see at the rural level, you do need the people to feel like they can take initiatives and a number of people to emerge leaders who can lead teams, impart skills to the teams and so on ...”.

"... Change management is a very important aspect. Policy is all very well, policy process. But to implement policies you have to know not just the legal but the institutional, operational, technical, financial nature of change".

With regard to curriculum development, i.e. what training programs need to be developed, it is interesting to note that the experts developed different views about it in many respects. This is what one of the experts said about the need for in-service training:

"... In-service training with implementation of specific projects in the workplace. At that, the civil servant receives coaching on the development of the projects and their immediate implementation. Such projects can be preagreed with the management of civil servant".

In addition the majority of experts agreed that it is very important to have experience and knowledge of the context during the work process. Therefore, the experts proposed to develop programs oriented at real situations and specific examples (case studies):

"Second issue is again experience. You at the moment have got a lot of very well-educated civil servants who have got Phds, who studied abroad and 
so on. In my experience that is unique, I haven't seen that in other countries. The one problem is that they need the experience on the ground. They need to know the context and content. I listen to some of your workshops and it seems to me it is dealing more with law and basis. Legislation is just a beginning, a first step. But the thing is how it will be implemented in practice. For that reason I think there needs to be more practical experience. In other words, the learning should be focused more on studying and analyzing the real situations".

Also, the example most commonly used by the experts, is the training focused on development of the civil servants' specific competencies.

When considering the issue of the training methods, the experts mutually agreed that the training should be active, in order to represent so called "active learning". The majority of experts expressed their views on the fact that the traditional methods of education are important, but they are less effective nowadays. Some of the experts' comments on this matter were as follows:

“... Results of my study have shown that the most effective training for adults is experiential learning, which by necessity have to include the active learning (Study, Application, Analysis), i.e. not only the study in the classroom. Based on the results of my interviews with civil servants in leadership positions, the most effective training methods involve the work with successful managers, and monitoring their performance; in-service training; development of so-called «Stretch assignments» (special tasks for stimulating further development); organization of mentoring in government agency; and organization of off-site trainings to familiarize with international experience".

Another expert has noted that active learning should be accompanied by group work, work in pairs, and in some cases, by individual work. It is necessary to structure the training courses in a way so that civil servants have the opportunity to express themselves, since each of them comes with a certain amount of knowledge and experience, and no matter whether it is a good experience or not, this is their experience. Based on their experience, you need to enable them to construct this new knowledge by themselves while working and discussing the issues in groups or in pairs:

"Civil servants need to understand that they're learners. Every civil servant has to have, first of all, a professional development plan and that should be linked logically to an appraisal system, and that implies managers have got some knowledge to be able to manage all of this and help them to identify what they want to learn and so on. So, professional development I see as an essential kind of modality for every civil servant ...”.

So-called "peer learning" (group exchange of experience and knowledge) was also a commonly used example in interviewees' responses.

Thus, the international experts pointed out the importance of developing leadership skills while simultaneously developing managerial skills. The training methods proposed by the experts are of particular interest. They are all focused on enhancing the interactive training methods involving trainees themselves into the training process. Results of the interviews are summarized in Table 6. 
0
$\frac{0}{0}$
$\frac{0}{0}$

\begin{tabular}{|c|c|c|c|c|c|c|c|c|c|c|c|c|}
\hline 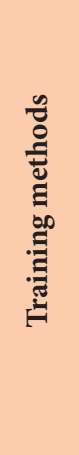 & 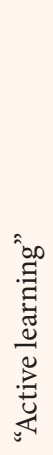 & 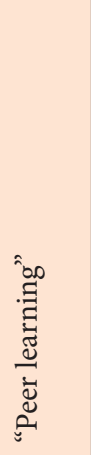 & 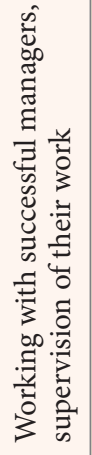 & 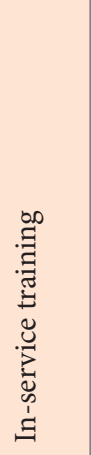 & 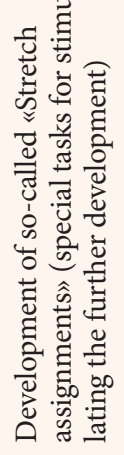 & 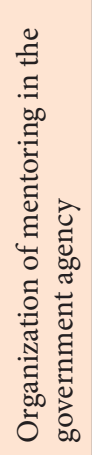 & 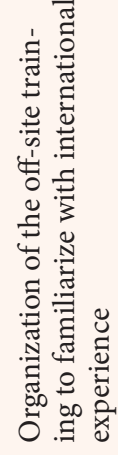 & 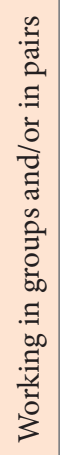 & 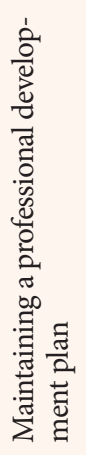 & & & \\
\hline 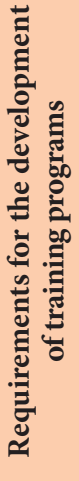 & 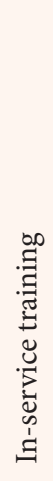 & 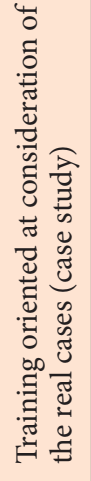 & 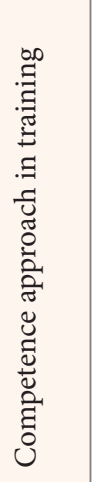 & & & & & & & & & \\
\hline 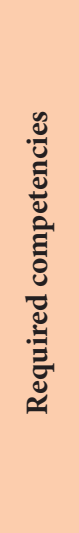 & 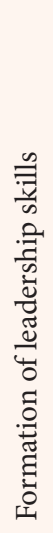 & 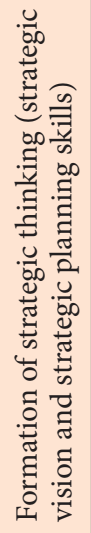 & 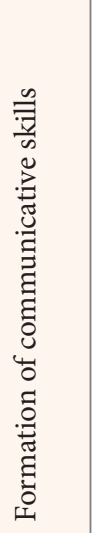 & 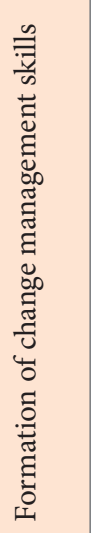 & 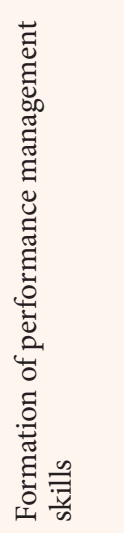 & 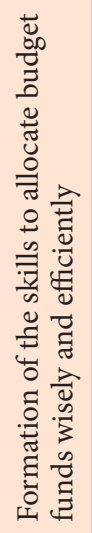 & 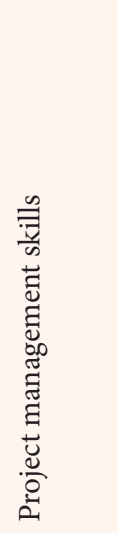 & 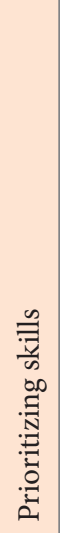 & 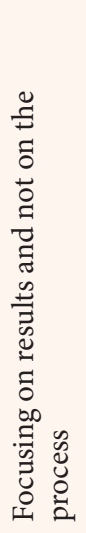 & 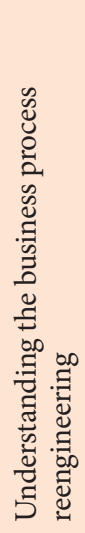 & 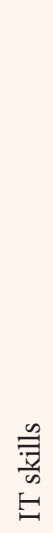 & 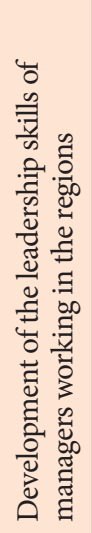 \\
\hline 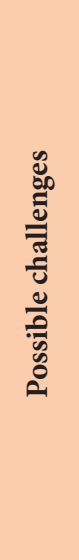 & 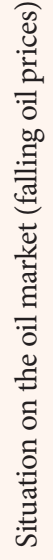 & 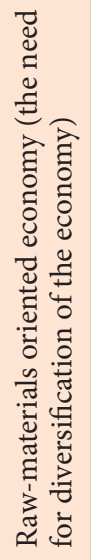 & 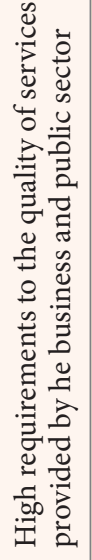 & 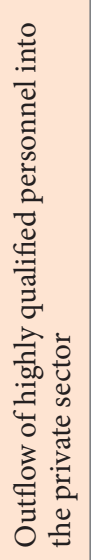 & 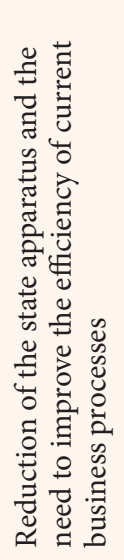 & 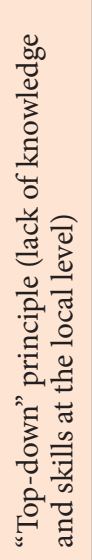 & & & & & & \\
\hline
\end{tabular}




\section{Conclusion}

Both quantitative and qualitative results confirm that civil servants universally recognize that certainly there are some gaps between what is required to perform their work completely and what they actually know. According to the findings of the study there are skill areas which present a catalogue that is essential to Kazakhstani civil servants professional development. Results of the study suggest that training is needed across the following areas:

1) Ability to communicate effectively;

2) Project management skills;

3) Skills in research, analysis;

4) Development of leadership skills;

5) Strategic planning and budgeting skills;

6) Fundamental knowledge of policy definition, implementation and evaluation;

7) Ability to make right decisions.

The focus and methodology of the training also requires critical attention. A training priority might be emphasizing the role of in-service training where trainees can reflect and learn from their own experience.

This study is only an initial investigation. The sample is limited and the results may not be generalizable to the entire civil service system in Kazakhstan. It is recommended to extend the number of survey participants in order to collect more quantified data from civil servants of different regions of Kazakhstan. However, trends and issues related to civil servants' current training needs have been identified. The above represents the current target topics of a training curriculum. Training centers developing the training programs should pay attention to the performance gap between current competencies and their actual training needs. It can be concluded that training needs assessment is very important in planning training programmes. So, it is of great importance to conduct training needs assessments among civil servants on a regular basis.

\section{Acknowledgements}

The authors express special gratitude to Professor Alexey Barabashev,

Scientific Supervisor of the Faculty of Social Science, School of Public Administration, Department of Public and Local Service, Head of Program "HR Management in the Public sector" for his thorough review of the article, valuable comments and recommendations.

Also the authors thank the staff of the Institute for Civil Servants Executive Education of the Academy of Public Administration under the President of the Republic of Kazakhstan, namely Svetlana Mussenova, Zhanar Seitkazina, Assel Sadvakassova, and other colleagues for their help during the data collection process. 


\section{REFERENCES}

1. Applegarth, M. (1991). How to Take a Training Audit. London: Kogan Page Ltd.

2. Asatryan, S., Heinemann, F. \& Pitlik, H. (2015). Reforming the Public Administration: The Role of Crisis and the Power of Bureaucracy. Discussion Paper No. 15-049. Available at: http:// ftp.zew.de/pub/zew-docs/dp/dp15049.pdf

3. Balisi, Sh. (2014). Training Needs Assessment in Botswana Public Service: A Case Study of Five Ministries. Teaching Public Administration, vol. 32, no 2, pp. 127-143.

4. Barabashev, A. \& Klimenko, A. (2017). Russian Governance Changes and Performance. Chinese Political Science Review, vol. 2, no 1, pp. 22-39.

5. Barabashev, A.G. (2016). Are Existing Administrative Paradigms Capable of Providing Tools to Resolve the Contemporary Administrative Crisis? Public Administration Issues, no 5 (Special Issue, electronic edition), pp. 6-25 (in English).

6. Barabashev, A. (2011). Basic Models for Civil Service Training: Possibilities of its Implementation in Russia. Available at: https://publications.hse.ru/mirror/pubs/share/.../77192166 (accessed: 26 December, 2017).

7. Barbazette, J. (2006). Training Needs Assessment: Methods, Tools and Techniques. San Francisco, CA: Pfeiffer

8. Bhuyian, H. Sh. \& Amagoh, F. (2011). Public Sector Reform in Kazakhstan: Issues and Perspectives. International Journal of Public Sector Management, vol. 24, no 3, pp. 227-249.

9. Civil Service Competency Framework. (2015). Available at https://www.gov.uk/government/ uploads/system/uploads/attachment_data/file/436073/cscf_fulla4potrait_2013-2017_v2d. pdf (accessed: 26 December, 2017).

10. Civil Service: Training and Development (2014). Available at https://www.gov.uk/guidance/training-and-development-opportunities-in-the-the-civil-service (accessed: 26 December, 2017).

11. Chang, J.Ch, Chiang, Tseng-Chang \& Kun yi, Chen (2012). The Systematic Construction and Influential Factors of Training Needs Assessment. International Journal of Business and Social Science, vol. 3, no 24, pp. 31-41.

12. Cojocaru, L., Falaris, E.M., Hoffman, S.D. \& Miller, J.B. (2016). Financial System Development and Economic Growth in Transition Economies: New Empirical Evidence from the CEE and CIS Countries. Emerging Markets Finance and Trade, vol. 52, no 1, pp. 223-236.

13. Demmke, Ch., Hammerschmid, G. \& Meyer, R. (2006). Decentralisation of HR Practices A European Comparative Perspective. Paper presented at EGPA Conference, Study Group III Personnel Policies, September, Milan, Italy.

14. Franko, P. \& Stamos Jr. S. (2017). The Puzzle of Twenty-First-Century Globalization: An International Economics Primer. USA: Rowman \& Littlefield

15. Fourie, D. (2004). Training needs analysis for middle management: A South African public service experience. Journal of Public Administration, vol. 39, no 4.1, pp. 492-506

16. Haslinda, A (2009).Training Needs Assessment and Analysis: A Case of Malaysian Manufacturing Firms. Eur. J. Sci. Res., vol. 37, no 3, pp. 351-360.

17. Janenova, S. \& Kim P.S. (2016). Innovating Public Service Delivery in Transitional Countries: The Case of One Stop Shops in Kazakhstan. International Journal of Public Administration, vol. 39, no 4, pp. 323-333.

18. Kramer, R. (2016). From Skillset to Mindset: A New Paradigm for Leader Development. Public Administration Issues, no 5 (Special Issue, electronic edition), pp. 26-45 (in English). 
19. Knassmuller, M. \& Veit, S. (2015). Culture Matters - The Training of Senior Civil Servants in Austria, Germany, The Netherlands And Switzerland. Teaching Public Administration.

20. Lopez, A.L. (2017). New European Economic Governance Versus European Economic Government: From Market Constitutionalism toward a More Redistributive Constitutionalism. In: Democratic Legitimacy in the European Union and Global Governance Building a European Demos. Springer International Publishing, pp. 221-237.

21. Manning, N. \& Agere, S. (2002). Current Good Practices and New Developments in Public Sector Management. London: Commonwealth Secretariat.

22. Manual on training needs assessment. project on improvement of local administration in cambodia (PILAC) Ministry of Interior and Japan International Cooperation Agency. Available at: www. jica.go.jp/project/cambodia/0601331/.../3_TNA_02.pdf (accessed: 26 December, 2017).

23. Matei, A., Bujac R. (2016). Innovation and Public Reform. Procedia Economics and Finance, Vol. 39, pp. 761-768. Available at SSRN: https://ssrn.com/abstract=2810833 (accessed: 26 December, 2017).

24. Miglic, G. (2006). Professional Training Needs Analysis Procedure (Manual). Belgrad

25. Mosley, L. \& Singer, D. (2015) Migration, labor, and the international political economy. Annual Review of Political Science, no 18, pp. 283-302

26. Mulang, A. (2015). Importance of Training for Human Resource Development in Organization. Journal of Public Administration and Governance, vol. 5, no 1, pp. 190-197.

27. National Digital History (2017). Available at http://e-history.kz/en/contents/view/452 (accessed: 26 December, 2017).

28. Nemec, J. (2014). Comparative Analysis of Public Administration Reforms in Former Socialist Countries of Central and Eastern Europe. International Journal of Civil Service Reform \& Practice, no 4, pp. 93-113.

29. Kim, P.S. (2016). Innovating Training and Development in Government: The Case of South Korea in Sharpening the Sword of State: Building Executive Capacities in the Public Services of the Asia-Pacific. ANU Press, pp. 125-140.

30. Podger, A. (2016). Public Sector Executive Development in the Asia-Pacific: Different Contexts but Similar Challenges in Sharpening the Sword of State: Building Executive Capacities in the Public Services of the Asia-Pacific (2016). ANU Press, p. 258.

31. Poor, J. (2008). Training under Changes in Public Sector - Eastern European Perspectives. Paper presented at MEB 2008 - 6th International Conference on Management, Enterprise and Benchmarking, May. Budapest, Hungary.

32. Randma-Liiv, Tiina, Merilin Metsma \& Külli Sarapuu (2013). Between Continuity and Change: The Analysis of the Estonian Civil Service Training System. In: Mirko Vintar, Allan Rosenbaum, György Jenei and Wolfgang Drechsler (eds). The Past, Present and the Future of Public Administration in Central and Eastern Europe. Bratislava: NISPAcee Press.

33. Reichard, C. (2016). Academic executive programs in public administration and management: some variety across Europe. Teaching Public Administration, vol. 35, no 1, pp. 126-138.

34. Rivolin, U. J. (2017). Global crisis and the systems of spatial governance and planning: a European comparison. Journal European Planning Studies, pp. 1-19.

35. Rodic, B., Vukovic, G., Zarsnik, B. \& Miglic, G. (2012). Issues in Introducing Training Needs Analysis in Slovenia's Public Administration. Transylvanian Review of Administrative Sciences, no 37 (E), pp. 155-171.

36. Sheal, P. (1994). How to Develop and Present Staff Training Courses. London: Kogan Page Ltd.

37. Stephen, P. R. (2001). Organizational Behavior (9th ed.). Englewood Cliffs, NJ: Prentice Hall. 
38. Subari, S. \& Riady, H. (2015). Influence of Training, Competence and Motivation on Employee Performance, Moderated by Internal Communications. American Journal of Business and Management, vol. 4, no 3, pp. 133-145.

39. Suleimenova, G. (2016). Civil Service Training in Kazakhstan: The Implementation of New Approaches. Universal Journal of Educational Research, vol. 4, no 10, pp. 2347-2354.

40. Suleimenova, G. \& Demeuova, A. (2014). Training of Civil Servants at the Academy of Public Administration under the President of the Republic of Kazakhstan: Paper presented at the annual conference Government vs. Governance in Central and Eastern Europe. From PreWeberianism to Neo-Weberianism? May. Budapest, Hungary

41. The OPM Training Needs Analysis. Available at: https://www.opm.gov/services-for-agencies/ assessment-evaluation/competency-gap-analysis\#url=Training-Needs-Analysis (accessed: 26 December, 2017).

42. The OPM Training Evaluation Field Guide. Available at: http://www.opm.gov/policy-dataoversight/training-and-development/reference-materials/training_evaluation.pdf (accessed: 26 December, 2017).

43. Topno, H. (2012). Evaluation of Training and Development: An Analysis of Various Models. Journal of Business and Management (IOSR-JBM), vol. 5, no 2, pp. 16-22.

44. Van Wart, M., Hondeghem, A., Schwella, E. \& Suino, P. (2015). Leadership and Culture: Comparative Models of Top Civil Servants Training. UK: Palgraive Macmillan

45. Dukhnich Y. (2007). Vyavleniye potrebnostei v obuchenii personala [Personnel training needs finding]. Available: http://www.smart-edu.com/vyyavlenie-potrebnosti-v-obucheniipersonala.html

46. Kazhyken M. (2015). Model adaptivnoi ekonomiki: normativnyi podkhod (diskussionnaya stat'ya) [The model of adaptive economy: normative approach (discussion article). Available at URL: http://www.kazneb.kz/bookView/view/?brId=1508892\&simple=true\#

47. Nisnevich. Y. (2012). Gosudarstvo XXI veka: tendencii I problem razvitiya [XXI century state: tendencies and development problems] - M.: KnoRus.

48. Realizatsiya novoi modeli gosudarstvennoi sluzhby (2017). [The realization of new model of civil service]. Available at http://kyzmet.gov.kz/ru/pages/realizaciya-novoy-modeligosudarstvennoy-sluzhby-26012017

\section{DOCUMENTS}

1. Agentstvo Respubliki Kazakhstan po delam gosudarstvennoi sluzhby I protivodeistviyu korrupcii (2016) [Agency of the Republic of Kazakhstan for civil service and to anticorruption]. Available: http://kyzmet.gov.kz/ru/ (accessed: 26 December, 2017).

2. Zakon Respubliki Kazakhstan "O gosudarstvennoi sluzhbe Respubliki Kazakhstan” [Law of the Republic of Kazakhstan "On civil service of the Republic of Kazakhstan]. Available at www.adilet.zan.kz

3. Informaciya ob osnovnykh itogakh deyatelnosti v sfere gosudarstvennoi sluzhby za 2016 god [Information on the main results of activity in the sphere of civil service for 2016]. Available: http://kyzmet.gov.kz/ru/pages/informaciya-ob-osnovnyh-itogah-deyatelnosti-v-sferegosudarstvennoy-sluzhby-za-2016-god-0

4. Informaciya ob osnovnykh itogakh deyatelnosti v sfere gosudarstvennoi sluzhby za 2015 god [Information on the main results of activity in the sphere of civil service for 2015, n.d.]. http://kyzmet.gov.kz/ru/pages/informaciya-ob-osnovnyh-itogah-deyatelnosti-v-sferegosudarstvennoy-sluzhby-za-2015-god 